\title{
ANGON SAMPAH SEBAGAI UPAYA PEMBERDAYAAN MASYARAKAT BER- BASIS POTENSI LOKAL DI DESA PESUCEN MELALUI TEORI DIGNAN
}

\author{
Angon Sampah As A Empowerment Efforts Based On Local \\ Potential In Pesucen Through Dignan Theory \\ Inriza Yuliandari ${ }^{1}$, Nenda Puspita Sari ${ }^{2}$, Rochmad Ardiansyah ${ }^{3}$, Novayanti Nur ${ }^{4}$ \\ Universitas Airlangga \\ Email: inriza.yuliandri-2015@fkm.unair.ac.id (+62812-3260-2389)
}

\begin{abstract}
ABSTRAK
Sampah adalah salah satu masalah kesehatan masyarakat yang masih banyak dihadapi oleh masyarakat Indonesia saat ini. Menurut data dari Kementerian Lingkungan Hidup dan Kehutanan Republik Indonesia (2018), jumlah sampah, utamanya sampah plastik di Indonesia, telah mencapai level yang mengkhawatirkan dengan tren meningkat dalam rentang waktu 10 tahun terakhir. Banyuwangi sebagai salah satu kabupaten di Indonesia juga menghadapi masalah sampah, utamanya di wilayah Kecamatan Kalipuro Desa Pesucen. Tidak adanya tempat pembuangan sampah yang memenuhi syarat dan Tempat Pembuangan Sampah Sementara (TPS) membuat masyarakat sekitar sering membuang sampah sembarangan, dan bahkan membakarnya setiap kali ada sampah menumpuk sehingga dapat mengganggu kesehatan masyarakat sekitar. Melihat permasalahan tersebut, diadakanlah program kegiatan pemberdayaan masyarakat di Desa Pesucen dengan nama Angon Sampah (Gancang Podo Nyelengi Sampah) untuk meminimalisasi permasalahan sampah di Desa Pesucen. Melalui artikel ini, penulis akan menyampaikan perencanaan dan implementasi Angon Sampah (Gancang Podo Nyelengi Sampah) melalui Teori Dignan. Penelitian dilakukan secara observasional menggunakan pendekatan kualitatif dengan jenis penelitian yang bersifat deksriptif. Kesimpulan yang didapat adalah Angon Sampah (Gancang Podo Nyelengi Sampah) merupakah salah satu program pemberdayaan masyarakat yang cukup efektif untuk mengurangi sampah di Dusun Bangorejo Desa Pesucen.
\end{abstract}

Kata Kunci $\quad$ : Bank sampah, Dignan, pemberdayaan, sampah

\section{ABSTRACT}

Garbage is one of the public health problems that many Indonesians still face today. According to Ministry of Environment and Forestry of the Republic of Indonesia (2018), the amount of waste, mainly plastic waste in Indonesia, has reached an alarming level with an increasing trend over the past 10 years. Banyuwangi, as one of the regencies in Indonesia, also faces a garbage problem, especially in the Kalipuro District of Pesucen Village. The absence of a garbage dump and Temporary Waste Disposal Site make the surrounding community often litter and even burn the rubbish piles that affect health problems in surrounding community. Seeing these problems, a community empowerment activity program was held in Pesucen Village with the name Angon Sampah (Gancang Podo Nyelengi Sampah) to minimize waste problems in Pesucen Village. Through this paper, the author will deliver planning and implementation of Angon Sampah (Gancang Podo Nyelengi Sampah) program through Dignan's Theory. The study was conducted observationally using a qualitative approach with descriptive research type. The results is, Angon Sampah (Gancang Podo Nyelengi Sampah) program is one of the community empowerment program that is quite effective in reducing waste problems in Pesucen Village.

Keywords : Dignan, empowerment, garbage, waste bank

\footnotetext{
Sekretariat

Editorial: Kampus FKM UNISMUH PALU - Palu 94118, Sulawesi Tengah, Indonesia

Telp/HP: +6281245936241, Fax (0451) 425627

E-mail: jurnal.mppki@gmail.com

OJS: http://jurnal.unismuhpalu.ac.id/index.php/PJKM
}

\author{
Article History: \\ $\Rightarrow \quad$ Received 04 September 2018 \\ $\Rightarrow \quad$ Revised 03 Oktober 2018 \\ $\Rightarrow \quad$ Accepted 20 November 2018 \\ $\Rightarrow \quad$ Available online 31 Desember 2018
}




\section{PENDAHULUAN}

Menurut Undang-Undang Republik Indonesia No. 18 Tahun 2008 tentang pengelolaan sampah, sampah adalah sisa yang ditimbulkan oleh manusia dan/atau proses alam dalam kegiatan sehari-hari yang berbentuk padat. Mukono (2006) menyebutkan bahwa sampah padat dibedakan menjadi beberapa jenis, antara lain: berdasarkan kandungan zat kimia, berdasarkan mudah atau sukarnya terbakar, dan mudah atau sukarnya membusuk. Berdasarkan jenis dalam mudah atau sukarnya membusuk, sampah dibedakan menjadi; sampah yang sukar membusuk, seperti plastik, styrofoam, botol, dan lain sebagainya; dan, sampah yang mudah membusuk, seperti daun kering, sisa makanan, dan lain sebagainya.

Sampah adalah salah satu masalah kesehatan masyarakat yang masih banyak dihadapi oleh masyarakat Indonesia saat ini. Agus dalam Eppang (2016), menyampaikan bahwa di Indonesia, jumlah sampah padat dapat mencapai 151.921 ton secara nasional per hari. Artinya, masing-masing individu di Indonesia membuang sampah dengan rata-rata sebesar 0,85 kilogram setiap harinya. Menurut data dari Kementerian Lingkungan Hidup dan Kehutanan Republik Indonesia (2018), jumlah sampah, utamanya sampah plastik di Indonesia, telah mencapai level yang mengkhawatirkan dengan tren meningkat dalam rentang waktu 10 tahun terakhir. Pernyataan tersebut juga diperkuat oleh pernyataan dari Novrizal dalam Pitoko (2018), jumlah sampah plastik telah meningkat frekuensinya sebanyak 5 persen dari tahun 2002 (11 persen) hingga tahun 2016 (16-17 persen). Jika dibiarkan secara terus-menerus, komposisi sampah plastik mungkin akan menjadi lebih dari 25 persen pada tahun 2030 dan terus meningkat hingga 40 persen di tahun 2050 , dan hal tersebut menyebabkan jumlah sampah yang lebih banyak daripada ikan di laut (Novrizal dalam Pitoko (2018)). Tidak hanya terganggunya biota laut, Agus dalam Eppang (2016) menyampaikan pengelolaan sampah yang kurang baik juga dapat mengganggu lingkungan sekitar, karena penelitiannya juga menunjukkan bahwa sebanyak sebanyak 24,8 persen masyarakat Indonesia masih membakar sampah yang dimiliki.
Salah satu usaha yang dapat dilakukan untuk mengatasi masalah sampah di Indonesia oleh berbagai pihak adalah melalui pemberdayaan masyarakat. Widayanti dalam Mustangin (2017) menyebutkan bahwa pemberdayaan masyarakat menjadi perhatian publik, yang disebut dapat dijadikan suatu pendekatan yang sesuai dalam segala jenis mengatasi permasalahan yang ada, seperti: sosial, ekonomi, lingkungan, dan lain sebagainya yan dapat dilaksankan oleh berbagai tingkat lembaga, mulai dari pemerintah, dunia usaha, dan masrakat biasa melalui Organisasi Masyarakat Sipil. Intinya, pemberdayaan masyarakat adalah suatu upaya untuk memberikan daya atau kemampuan bagi masyarakat agar dapat keluar dari masalah-masalah yang dihadapinya, sehingga masyarakat tersebut dapat hidup mandiri dan dapat menghadapi segala jenis rintangan di kehidupannya.

Kaitannya dengan masalah sampah di Indonesia, pemberdayaan masyarakat dapat dilakukan dalam berbagai bentuk, salah satunya adalah melalui program bank sampah. Menurut Utami (2013), bank sampah adalah suatu sistem yang saling berhubungan dan berkesinambungan yang mendorong masyarakat untuk aktif untuk mengatasi masalah sampah di lingkungan sekitar yang dilakukan secara kolektif oleh masyarakat itu sendiri atau melalui kerjasama dengan pihakpihak yang terkait. Sistem dalam Bank Sampah memiliki berbagai macam tahap, seperti: menampung, memilah, dan menyalurkan sampah yang memiliki nilai ekonomi pada pasar yang membutuhkan sehingga selanjutnya masyarakat mendapatkan profit dari kegiatan tersebut. Sama halnya dengan sistem bank pada umumnya, bank sampah juga memiliki sistem manajerial yang kegiatannya dilakukan oleh masyarakat itu sendiri. Sampah yang dikumpulkan oleh masyarakat harus mengalami proses pemilahan terlebih dahulu agar selanjutnya dapat disetorkan ke pasar. Kegiatan ini dapat memotivasi masyarakat untuk memilah dan mengelompokkan sampah, misalnya berdasarkan jenis material kaca, plastik, metal, dan kaca. Mekanisme yang dilakukan dalam kegiatan bank sampah adalah pemilahan sampah rumah tangga, penyetoran sampah ke bank, penimbangan, pencatatan, dan pengangkutan. 
Banyuwangi sebagai salah satu kabupaten di Indonesia juga menghadapi masalah sampah, utamanya di wilayah Kecamatan Kalipuro Desa Pesucen. Desa Pesucen terdiri dari 4.224 penduduk jiwa yang terbagi dalam tiga dusun yaitu Dusun Krajan, Dusun Bangorejo, dan Dusun Padangbaru. Berdasarkan Profil Desa Pesucen tahun 2017, masyarakat desa Pesucen ditinjau dari segi ekonomi didominasi dengan kategori keluarga sejahtera 1 disusul dengan keluarga prasejahtera dengan distribusi keluarga prasejahtera sebanyak 539 keluarga, keluarga sejahtera 1 sebanyak 755 keluarga, keluarga sejahtera 2 sebanyak 231 keluarga, keluarga sejahtera 3 sebanyak 15 keluarga. Desa Pesucen terletak di daerah dataran tinggi dengan lingkungan hijau dan asri serta suasana khas pegunungan yang sejuk dan bersih, sehingga akses untuk menuju ke wilayah perkotaan cukup sulit. Perilaku masyarakat Desa Pesucen masih banyak yang membuang sampah sembarangan, atau membakar sampah di halaman rumahnya. Tak elak, masalah kesehatan di Desa Pesucen juga memiliki prevalensi yang tinggi (Puskesmas Kelir, 2018). Hal tersebut juga disebabkan oleh tidak adanya tempat pembuangan sampah yang memenuhi syarat dan tidak adanya Tempat Pembuangan Sampah Sementara (TPS) sehingga masyarakat Pesucen seringkali membuang sampah di sungai, dan di jurang terdekat, dan bahkan membakarnya setiap kali ada sampah menumpuk sehingga dapat mengganggu kesehatan masyarakat sekitar.

Melihat permasalahan tersebut, mahasiswa Kelompok 1 Praktik Kerja Lapangan Program Studi Kesehatan Masyarakat Fakultas Kesehatan Masyarakat PSDKU Universitas Airlangga di Banyuwangi pun mengadakan program kegiatan pemberdayaan masyarakat di Desa Pesucen dengan nama Angon Sampah (Gancang Podo Nyelengi Sampah). Melalui artikel ini, penulis akan menyampaikan perencanaan dan implementasi kegiatan melalui Teori Dignan.

\section{BAHAN DAN METODE}

Penelitian ini menggunakan pendekatan kualitatif dengan jenis penelitian yang bersifat deksriptif. Penelitian dilakukan dengan mencari informasi mengenai penelitian sebelumnya dan data tambahan mengenai wilayah yang rawan dengan masalah sampah dan upaya pemberdayaan masyarakat dalam mengatasi masalah sampah di Indonesia, utamanya di Banyuwangi. Berdasarkan kajian studi pendahuluan tersebut, salah satu desa di Banyuwangi yang rawan masalah sampahnya adalah Desa Pesucen, sehingga Desa Pesucen dipilih sebagai tempat untuk implementasi program terkait sampah, yaitu bank sampah dengan nama $A n-$ gon Sampah Pesucen. Lokasi spesifik implementasi kegiatan ini adalah RW 3 Dusun Bangorejo Desa Pesucen. Waktu penelitian ini adalah 2 Juli 2018 hingga 9 Agustus 2018. Sumber data didapatkan dari hasil pengamatan observasional secara langsung mengenai implementasi program. Metode analisis yang digunakan dalam implementasi program pemberdayaan masyarakat ini adalah sesuai dengan kerangka Teori Dignan. Sehingga, gagasan yang diusulkan harus sesuai dengan keadaan masyarakat dan sesuai dengan nilai-nilai yang dianut masyarakat.

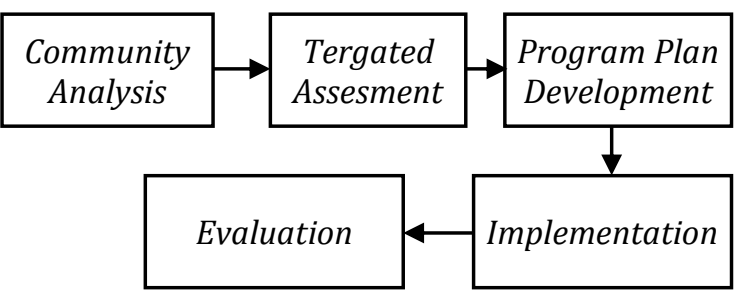

Sumber : Dignan \& Carr (1992)

Gambar 1. Skema Perencanaan Program dalam Kerangka Teori Dignan

\section{HASIL}

Angon Sampah, yang merupakan kependekan dari Gancang Podo Nyelengi Sampah, adalah suatu program pemberdayaan masyarakat untuk mengurangi masalah sampah, utamanya di Desa Pesucen. Program ini terdiri dari berbagai kegiatan yang berkaitan satu sama lain, yaitu pemberian materi mengenai pengelolaan sampah oleh pemateri dari Bank Sampah Banyuwangi dan LSM Lingkungan Kilisa Desain, serta kegiatan pelatihan bank sampah agar selanjutnya program ini dapat berkelanjutan di Desa Pesucen dan bahkan menjadi percontohan bagi wilayah lainnya. Tujuan dari program Angon Sampah untuk meningkatkan kapabilitas masyarakat dalam mengurangi masalah sampah yang ada di Desa Pesucen sesuai kaidah SMART, yai- 
tu: 30\% (18 orang) dari 60 KK RW 3 Dusun Bangorejo Desa Pesucen tertarik untuk mengikuti kegiatan Angon Sampah pada hari pertama dan hari ke dua, dilihat dari absensi. Tujuan tersebut dapat dilihat melalui indikator ketercapaian program yang telah direncanakan sebelumnya. Tujuan tersebut berhasil dicapai, karena pada implementasinya: (1) Kegiatan pemberian materi: 63,3\% (38 orang) dari 60 KK RW 3 Dusun Bangorejo Desa Pesucen mengikuti kegiatan Angon Sampah dua kali di tanggal 27 dan 29 Juli 2018, (2) Kegiatan pelatihan: 95\% (57 orang) dari 60 KK RW 3 Dusun Bangorejo Desa Pesucen mengikuti kegiatan Angon Sampah. Bentuk pemahaman masyarakat mengenai program kegiatan Angon Sampah dapat dilihat melalui terbentuknya kelompok Bank Sampah Pos Bangun Ceria di RW 03 Dusun Bangorejo yang aktif bekerjasama dengan Bank Sampah Banyuwangi. Selain itu juga terpilih dan terbentuknya kader Bank Sampah untuk menjaga sustainabilitas program. Program ini menggunakan metode pemberdayaan masyarakat berbasis lingkungan. Lokasi spesifik pelaksanaan program ini adalah di RW 3 Dusun Bangorejo yang direncanakan sebagai dusun percontohan dalam pengelolaan sampah di Desa Pesucen.

\section{PEMBAHASAN}

Angon Sampah sebagai salah satu program pemberdayaan masyarakat dimaksudkan untuk menumbuhkan kesadaran dan kemandirian masyarakat dalam mengelola sampah agar selanjutnya masyarakat dapat hidup dengan lebih baik melalui upaya pemanfaatan berbagai potensi yang ada di suatu desa, utamanya di Desa Pesucen Banyuwangi. Pemberdayaan masyarakat melalui program Angon Sampah juga dimaksudkan untuk memberi kontribusi bagi pembangunan ekonomi di suatu desa. Perencanaan dan pelaksanaan program Angon Sampah di Desa Pesucen didasarkan pada kerangka Teori Dignan, sehingga gagasan yang diusulkan sesuai dengan keadaan masyarakat dan sesuai dengan nilai-nilai yang dianut masyarakat.

\section{Community Analysis}

Community analysis adalah tahap awal perencanaan program melalui analisis masalah berdasarkan segala bidang yang yang ada di suatu komunitas, seperti di bidang pendidikan, sosial, pekerjaan, masalah kesehatan, lingkungan, fasilitas kesehatan setempat, dan bidang lainnya yang mempengaruhi (Dignan \& Carr, 1992). Analisis komunitas yang didapatkan di Desa Pesucen dapat dilihat melalui berbagai macam aspek. Berdasarkan Profil Desa Pesucen (2017), banyak aspek-aspek di Desa Pesucen yang dapat dianalisis. Di aspek sosial, karakteristik sosial masyarakat Desa Pesucen yaitu masih memegang teguh sifat gotong royong di dalam kegiatan desa. Kegiatan sosial lain yaitu masih aktifnya kegiatan perkumpulan masyarakat seperti pengajian dan PKK. Selain itu, interaksi sosial lain juga didukung melalui kegiatan perlombaan antar dusun sebagai bentuk untuk menumbuhkan masyarakat dengan jiwa penuh sportifitas. Di aspek perilaku dan lingkungan sebagai penentu spesifik masalah kesehatan masyarakat yaitu sampah di Desa Pesucen, sampah merupakan masalah yang sangat kompleks dan merupakan masalah yang selalu ada di setiap tahunnya di Desa Pesucen. Masalah kesehatan masyarakat mengenai sampah timbul akibat beberapa faktor, yaitu; tidak adanya sarana dan prasarana, serta fasilitas pengelolaan sampah seperti Tempat Pembuangan Sampah Sementara (TPS) karena sulitnya akses menuju Desa Pesucen yang letaknya berada di daerah pegunungan dengan keadaan lingkungan masih mayoritas berupa kawasan hutan; kurangnya pengetahuan masyarakat tentang pengelolaan sampah sehingga tidak jarang sampah di Desa Pesucen akan dibuang di sungai atau jurang di dekat rumah masing-masing penduduk atau dibakar untuk mengurangi kuantitasnya; dan kurangnya sumber daya dari pemerintah, baik dari desa hingga daerah untuk mengatasi masalah sampah di Desa Pesucen.

\section{Targeted Assessment}

Setelah melakukan community analysis, dilanjutkan dengan penilaian sasaran secara spesifik yang akan diintervensi melalui program pemberdayaan ini. Penilaian sasaran dilakukan dengan memperhatikan jumlah sasaran yang akan diintervensi, lokasi strategis dari kegiatan yang akan dilakukan, jenis kelamin sasaran, kualitas sumber daya yang dimiliki, pekerjaan, dan pendidikan, serta perubahan perilaku yang diinginkan. Targeted assessment bersifat lebih subyeksional jika dibandingkan dengan community analysis 
yang masih memahami masalah secara global (Dignan \& Carr, 1992).

Desa Pesucen memiliki kelompok PKK di masing-masing dusunnya. Sebagai salah satu dusun di Desa Pesucen, Dusun Bangorejo juga memiliki kelompok PKK aktif melakukan empat kali kegiatan di setiap bulannya. Selanjutnya, ibu-ibu PKK RW 3 Dusun Bangorejo Desa Pesucen yang memiliki jadwal kegiatan yang telah ditentukan setiap minggunya akan menjadi sasaran program Angon Sampah. Ibu-ibu PKK RW 3 Dusun Bangorejo Desa Pesucen selanjutnya akan diberi suatu intervensi melalui program Angon Sampah untuk intervensi peningkatan pengetahuan dan perubahan perilaku yang diinginkan melalui pemberian materi dan pelatihan mengenai pengelolaan sampah.

\section{Program Plan Development}

Program plan development merupakan tahap perencanaan program yang dilakukan secara spesifik mengenai lokasi kegiatan, alat dan bahan yang digunakan, rencana implementasi program yang akan dilaksanakan dengan memperhatikan dasar model perubahan perilaku (Dignan \& Carr, 1992). Model perubahan perilaku yang sesuai dengan keadaan wilayah dan perencanaan program Angon Sampah ini adalah S-O-R, karena untuk merubah perilaku masyarakat utamanya ibu-ibu PKK dalam mengelola sampah di Desa Pesucen diperlukan suatu proses belajar yang saling berkelanjutan. Dalam teori S-O-R, terdapat tiga hal yang mendasari, yaitu:

1. Stimulus : Pengetahuan yang diberikan oleh pemateri mengenai pengelolaan sampah.

2. Organism : Sumber daya yang diperlukan untuk melakukan kegiatan perubahan perilaku melalui program pemberdayaan masyarakat. Contoh dalam program ini adalah ibu-ibu PKK Dusun Bangorejo Desa Pesucen.

3. Response : Feedback yang diberikan oleh ibu-ibu PKK dusun Bangorejo Desa Psucen sebagaisasaran kegiatan kepada pemateri. Response yang diharapkan adalah suatu bentuk keberlanjutan program.

Angon Sampah, yang merupakan kependekan dari Gancang Podo Nyelengi Sampah, adalah suatu program pemberdayaan masyarakat untuk mengurangi masalah sampah, utamanya di Desa Pesucen. Gancang Po- do Nyelengi Sampah merupakan suatu kalimat yang berasal dari Bahasa Jawa, yang artinya "Ayo bersama menabung sampah". Program ini menggunakan metode pemberdayaan masyarakat berbasis lingkungan. Selanjutnya, dilakukan suatu perencanaan program Angon Sampah (Gancang Podo Nyelengi Sampah) sebagai upaya minimalisasi sampah di Desa Pesucen. Kegiatan ini berbentuk pemberdayaan masyarakat dan advokasi dengan sasaran masyarakat Dusun Bangorejo Desa Pesucen Kabupaten Banyuwangi. Target kegiatan ini adalah $60 \mathrm{KK}$ yang berada di wilayah RW 3 Dusun Bangorejo. Tujuan kegiatan ini adalah untuk memberikan edukasi dan pelatihan mengenai sampah pada masyarakat Dusun Bangunrejo Desa Pesucen melalui kegiatan sosialisasi, pelatihan, dan kelembagaan. Adapun indikator keberhasilan dari kegiatan ini adalah adanya peningkatan antusiasme masyarakat RW 3 Dusun Bangorejo dalam mengikuti kegiatan Angon Sampah sebanyak 30\%, yang dilihat melalui kepersertaan masyarakat.

\section{Implementation}

Program Angon Sampah berlangsung dengan baik dan lancar sesuai dengan perencanaan program. Hal tersebut dapat dilihat melalui ketercapaian program yang sangat tinggi jika dibandingkan dengan indikator yang telah ditentukan sebelumnya, yaitu pada implementasinya:

(1) Kegiatan sosialisasi: 63,3\% (38 orang) dari 60 KK RW 3 Dusun Bangunrejo Desa Pesucen mengikuti kegiatan Angon Sampah dua kali di tanggal 27 dan 29 Juli 2018,

(2) Kegiatan pelatihan: 95\% (57 orang) dari 60 KK RW 3 Dusun Bangunrejo Desa Pesucen mengikuti kegiatan Angon Sampah.

Bentuk pemahaman masyarakat mengenai program kegiatan Angon Sampah dapat dilihat melalui terbentuknya kelompok Bank Sampah Pos Bangun Ceria di RW 03 Dusun Bangunrejo yang aktif bekerjasama dengan Bank Sampah Banyuwangi (BSB). Selain itu juga terpilih dan terbentuknya kader Bank Sampah untuk menjaga sustainabilitas program. Adapun nantinya RW 3 Dusun Bangunrejo akan dicanangkan sebagai dusun percontohan dalam implementasi program Angon Sampah.

Implementasi suatu program menurut 
Teori Dignan, harus mencakup aspek-aspek sebagai berikut:

\section{a) Gain Acceptance for the program} (Persetujuan Program): Pada tahap implementasi untuk mempermudah jalannya program, pelaksana program harus mendapatkan izin terlebih dahulu pada perangkat Desa Pesucen. Permohonan izin sudah dilaksanakan sebelumnya, program ini sepenuhnya disetujui oleh Kepala Desa Pesucen, Pihak Puskesmas Kelir, Kepala Dusun, dan Ketua RW 03, Ketua RT 01, RT 02 Dusun Bangunrejo.

b) Specify tasks and estimate resource needs (Tugas dan Kebutuhan Sumber Daya): Tahap ini merupakan tahap spesifikasi program dan masingmasing tugas sumber daya dan kebutuhan program.

c) Develop spesifc plans for program activities (Mengembangkan Rencana Spesifik untuk Kegiatan): Program Angon Sampah dilaksanakan di masjid dan dibelakang rumah ibu kades yang terdapat rumah kosong dengan lahan luas milik warga yang lokasinya strategis. Sumber daya dan penentuan tugas tidak hanya dari perencana program, namun juga dari warga desa dan mitra sosial. Program ini dilaksanakan 4 kegiatan yaitu: (1) merekrut kader bank sampah, (2) sosialisasi pengelolaan sampah, (3) praktek pengelolaan sampah, dan (4) struktur organisasi bank sampah Dusun Bangunrejo. Kegiatan berisi tentang penyuluhan atau pemberian informasi edukasi pada masyarakat sasaran terkait pengelolaan sampah, bank sampah, dan pembuatan kompos. Kegiatan ini dibantu oleh Dinas Lingkungan Hidup, dan Kilisa Desain. Kegiatan Angon Sampah dilakukan 2 kali, yaitu Jum'at 27 Juli 2018, dan Minggu 29 Juli 2018. Kegiatan Angon Sampah Pesucen yang pertama melakukan sosialisasi atau pemberian informasi edukasi kepada masyarakat tentang jenis sampah organik dan sampah non organik, bank sampah, pembuatan kompos, pengenalan kader. Untuk kegiatan $A n-$ gon Sampah yang kedua pemaparan mengenai bank sampah dan struktur organisasi Bank Sampah Banyuwangi yang dijelaskan oleh Bank Sampah Banyuwangi.

d) Establish mechanism for program management (Menetapkan Mekanisme untuk Manajemen Program):

\section{Pembentukan Kader}

Sebelum kegiatan Angon Sampah dilaksanakan yaitu pembentukan kader yang direkomendasikan oleh Ibu Kepala Desa.

\section{Sosialisasi}

Kegiatan Angon Sampah yang dilaksanakan Jum'at 27 Juli 2018 yaitu sosialisasi mengenai sampah organik dan sampah non organik, menjelaskan mengenai bank sampah beserta tata cara pembuatan pupuk kompos. Pada kegiatan Angon Sampah yang pertama terdapat 38 orang yang mengikuti kegiatan ini yang terdiri dari kepala desa, ketua RW 03, ketua RT 01, ketua RT 02 beserta masyarakat RW 03 Dusun Bangunrejo, Desa Pesucen, Kecamatan Kalipuro, Kabupaten Banyuwangi.

Kegiatan ini dilaksanakan setelah sholat Jum'at pukul 13.00 WIB. Kegiatan ini juga bertujuan mengajak masyarakat untuk mangikuti praktek pengelolaan sampah organik dan sampah anorganik. Sebelum acara dimulai peserta mengisi daftar hadir yang telah disediakan, setelah itu peserta dipersilahkan untuk duduk di tempat yang disediakan. Setelah peserta hadir dan berkumpul acara dimulai. Acara dibuka dengan berdoa bersama. Kemudian terdapat sambutan Kepala Desa Pesucen dan ketua PKL. Setelah itu pemaparan materi mengenai sampah organik, dan sampah anorganik, beserta pemisahannya. Di dalam materi pengelolaan sampah terdapat pengenalan mengenai bank sampah, dan langkah-langkah pembuatan pupuk kompos. Saat penyampaian materi peserta sangat antusias menyimak materi tersebut. Setelah penyampaian materi acara selanjutnya tanya jawab dan pembagian konsumsi. Peserta yang mengajukan pertanyaan selanjutnya akan diberi apresiasi berupa souvenir gelas. Setelah itu penutupan yang ditutup dengan doa penutup yang dibacakan oleh salah satu peserta. Sosialisasi kegiatan ini dapat dilihat pada Gambar 2 dan 3.

\section{Pelatihan}

Pelatihan pemanfaatan sampah dilaksanakan pada Minggu, 29 Juli 2018. Kegiatan ini dilaksanakan setelah warga ker- 
ja bakti di sekitar rumah mereka atau di sepanjang jalan di Dusun Bangunrejo. Pelatihan pengelolaan sampah terdiri dari pemanfaatan sampah organik dan pengelolaan sampah anorganik. Fokus pada artikel ini ada pemanfaatan sampah non-organik. Sebelum acara inti pelatihan dimulai, masyarakat melakukan kerjabakti di sekitar Dusun Bangunrejo. Setelah kerjabakti bersama mereka mengisi daftar hadir yang telah disediakan. Acara ini diawali dengan doa kemudian diisi oleh sambutan dari Kepala Desa Pesucen dan dosen pembimbing kelompok PKL. Setelah sambutan usai yaitu pemaparan materi mengenai bank sampah beserta memperkenalkan struktur organisasi Bank Sampah Banyuwangi. Selanjutnya praktek langsung mengenai pengelolaan bank sampah. Peserta pun sangat antusias menyimak pemaparan materi dan praktek langsung dalam pemanfaatan sampah. Kemudian, kegiatan pelatihan ditutup dengan membagikan konsumsi, foto bersama, dan pemberian kenang-kenangan kepada pemateri. Pelatihan mengenai bank sampah oleh Bank Sampah Banyuwangi kepada masyarakat dapat dilihat pada Gambar 4, 5, dan 6.

4. Pembentukan Bank Sampah Pesucen

Pembentukan Bank Sampah Pesucen dilaksanakan pada hari kamis tanggal 2 Agustus 2018. Kelompok ini selanjutnya menyebut pos sampah mereka dengan Pos Bangun Ceria, dengan pembagian kerja meliputi: ketua, sekretaris, bendahara, humas, penimbang, dan penyortir. Untuk mencari pelanggan yang akan menjual sampahnya pada pos sampah ini, Pos Sampah Bangun Ceria pun mensosialisasikan Bank Sampah Pesucen kepada masyarakat melalui pengajian Jamiyyah yang aktif dilaksanakan di Desa Pesucen. Kegiatan ini dapat dilihat pada gambar 7 dan 8 .

\section{Evaluation}

Evaluasi dalam Teori Dignan terdiri atas evaluasi proses dan evaluasi hasil. Evaluasi proses pelaksanaan program Angon Sampah dapat dilihat melalui implementasi kegiatan tersebut. Acara berjalan dengan lancar, sesuai program plan development yang telah ditentukan. Tetapi, terjadi ke-molor-an waktu karena masyarakat yang terlambat hampir 30 menit. Masyarakat sangat antusias dalam mengikuti kegiatan tersebut. Hal tersebut dapat dilihat melalui aktifnya tanya jawab yang dilakukan oleh masyarakat dengan pemateri mengenai cara pemilahan, dan harga jual sampah, Selanjutnya, kegiatan dilanjutkan dengan pelatihan program $A n$ gon Sampah mengenai Bank Sampah yang bekerjasama dengan Bank Sampah Banyuwangi dan Kilisa Desain Banyuwangi sebagai pematerinya. Sama seperti kegiatan sosialisasi, masyarakat sangat antusias dalam mengikuti kegiatan pelatihan. Hal tersebut dapat dilihat melalui aktifnya tanya jawab yang dilakukan oleh masyarakat dengan pemateri. Sustainabilitas program Angon Sampah dilanjutkan pada tanggal 2 Agustus 2018, ibu-ibu kader Bank Sampah RW 3 Dusun Bangunrejo Desa Pesucen mengundang Tim Mahasiswa PKL Pesucen untuk memberi ilmu tambahan mengenai pemberkasan dan pembentukan struktur organisasi. Kegiatan tersebut berlansung dengan baik dan lancar. Ibu-ibu juga sangat antusias terhadap kegiatan tersebut. Hal tersebut dapat dilihat melalui aktifnya tanya jawab yang dilakukan oleh masyarakat dengan pemateri. Selanjutnya, terbentuklah Bank Sampah Bangun Ceria sebagai nama kelompok Bank Sampah Dusun Bangunrejo Desa Pesucen. Pos Bank Sampah Sampah RW 3 Dusun Bangunrejo Desa Pesucen yang diketuai oleh Ibu Kepala Desa Pesucen. Pos Bank Sampah ini diletakkan di lahan kosong belakang rumah Kepala Desa.

Kemudian, evaluasi hasil untuk melihat antusias masyarakat dalam pelaksanaan program Angon Sampah dapat dilihat dengan membandingkan antara indikator keberhasilan program dengan ketercapaian program melalui absensi kehadiran. Berdasarkan indikator keberhasilan, 30\% (18 orang) dari 60 KK RW 3 Dusun Bangunrejo Desa Pesucen tertarik untuk mengikuti kegiatan Angon Sampah dalam waktu 14 hari yang dilihat melalui absensi kehadiran. Nyatanya, saat sosialisasi kegiatan Angon Sampah yang diadakan tanggal 27 Juli 2018, sebanyak 63,3\% (38 orang) dari 60 KK RW 3 Dusun Bangunrejo Desa Pesucen tertarik untuk mengikuti kegiatan Angon Sampah dalam waktu 14 hari. Tidak hanya sosialisasi saja, Tim Mahasiswa PKL Pesucen juga mengadakan pelatihan kegiatan Angon Sampah mengenai Bank Sampah dan pembuatan pupuk kompos. Antusiasme warga meningkat pada kegiatan tersebut. Hal tersebut 
dapat dilihat melalui absensi kehadiran, 95\% (57 orang) dari 60 KK RW 3 Dusun Bangunrejo Desa Pesucen tertarik untuk mengikuti kegiatan Angon Sampah dalam waktu 14 hari. Melalui hasil tersebut, dapat dilihat bahwa antusiasme warga RW 3 Dusun Bangunrejo Desa Pesucen sangat tinggi dalam mengikuti kegiatan Angon Sampah selama 14 hari.

\section{KESIMPULAN DAN SARAN}

Angon Sampah merupakah salah satu alternatif program pemberdayaan masyarakat untuk mengurangi sampah di Dusun Bangorejo Desa Pesucen. Konsep diadakannya program ini adalah berasal dari Bank Sampah. Untuk mencapai hasil program yang optimal, maka disusunlah organisasi pengurus sampah di wilayah tersebut. Organisasi tersebut bernama Pos Bangun Ceria yang beranggotakan ibu-ibu PKK yang aktif berorganisasi dan melakukan kegiatan sosial setiap minggunya. Ibu-ibu PKK tersebut selanjutnya akan menjalankan tugasnya masingmasing (administrasi, pemisahan, program sounding, dan penimbangan) sekaligus menjadi kader utama dan distributor langsung antara desa dan Bank Sampah Banyuwangi. Kegiatan ini diharapkan dapat bersifat berkelanjutan untuk mengasah kemandirian ibu-ibu PKK dalam peningkatan kepekaan terhadap lingkungan, sosial, dan ekonomi, melalui kegiatan Angon Sampah yang akan dilakukan di Dusun Bangorejo Desa Pesucen setiap satu bulan dua kali. Agar program ini dapat berkelanjutan dengan lancar, sebaiknya kelompok sampah Pos Bangun Ceria meningkatkan intensitas komunikasinya dengan pihak Bank Sampah Banyuwangi. Selain itu, Pos Bangun Ceria selaku kader pengolahan sampah di Dusun Bangorejo sebaiknya juga melakukan promosi kesehatan mengenai pemanfaatan sampah kepada para tetangga bahkan kepada ibu -ibu yang menjual sampah di pos ini.

\section{UCAPAN TERIMA KASIH}

Artikel ini didasarkan pada hasil Praktik Kerja Lapangan di Desa Pesucen oleh mahasiswa Fakultas Kesehatan Masyarakat PSDKU Universitas Airlangga di Banyuwangi. Penulis mengucapkan terimakasih kepada; (1) Allah SWT atas Rahmat-Nya, (2) orang tua (Cahyono Budi, dan Susiyati), dan Adi
Darma Nugroho yang selalu berdoa demi keberhasilan penulis, (3) anggota kelompok yang bekerja keras dalam menentukan masalah kesehatan masyarakat, dan mengimplementasikan kegiatan pemberdayaannya melalui kerjasama dengan berbagai pihak, (4) masyarakat Dusun Bangorejo Desa Pesucen yang telah memberikan waktu dan tenaganya untuk menjadi sasaran kegiatan, serta (5) Bank Sampah Banyuwangi dan LSM Lingkungan Kilisa Desain yang telah memberikan ilmu yang bermanfaat mengenai pengelolaan sampah.

\section{DAFTAR PUSTAKA}

Desa Pesucen. 2017. Profil Desa Pesucen. Banyuwangi.

Dignan, M.B., and Carr, P. A. 1992. Program Planning for Health Educational adan Promotion 2 nd Edition. USA: Lea and Febiger.

Eppang, Lince. 2016. Volume Sampah di Seluruh Dunia Mencapai 1,3 Miliar Ton. Netralnews. 13 November 2016. Yogyakarta. Melalui http:// www.netralnews.com/news/nasional/ $\mathrm{read} / 36022 /$ volume-sampah-diseluruh-dunia-mencapai-1-3-miliarton [diakses 17 September 2018].

Kementerian Lingkungan Hidup dan Kehutanan Republik Indonesia. 2018.

Mukono, H. J.. 2006. Prinsip Dasar Kesehatan Lingkungan. Edisi 2 (halaman 23). Surabaya: Airlangga University Press.

Mustangin, dkk.. 2017. "Pemberdayaan Masyarakat Berbasis Potensi Lokal Melalui Program Desa Wisata di Desa Bumiaji". Bandung: Jurnal Pemikiran dan Penelitian Sosiologi (Sosioglobal) Universitas Padjajaran. Volume 2, Nomor 1: halaman 60.

Pitoko, Ridwan Aji. 2018. Sampah Plastik di Indonesia Jadi Perhatian Presiden Bank Dunia. Kompas. 26 Juli 2018. Jakarta. Melalui https:// ekonomi.kompas.com/ $\mathrm{read} / 2018 / 07 / 26 / 135610326 /$ sampah-plastik-di-indonesia-jadiperhatian-presiden-bank-dunia [diakses 17 September 2018].

Pratama, dkk.. 2018. Laporan Praktik Kerja Lapangan di Desa Pesucen. Banyuwangi: Airlangga University Press. 
Puskesmas Kelir. 2018. Profil Kesehatan Desa Pesucen. Banyuwangi.

Sugiyono. 2010. Metode Penelitian Bandung (Pendekatan Kuantitatif, Kualitatif, dan $R \& D$ : Alfabeta.

Undang-Undang Republik Indonesia No. 18 Tahun 2008. Pengelolaan Sampah. 7 Mei 2008. Lembaran Negara Republik Indonesia Tahun 2008 Nomor 69. Jakarta.

Utami, Eka. 2013. Buku Panduan Sistem Bank Sampah. Jakarta: Yayasan Unilever Indonesia. Melalui https:// www.unilever.co.id/id/Images/bukupanduan-sistem-bank-sampah-10kisah-sukses-ina_tcm 1310 482082_id.pdf [diakses 17 September 2018]. 


\section{LAMPIRAN}

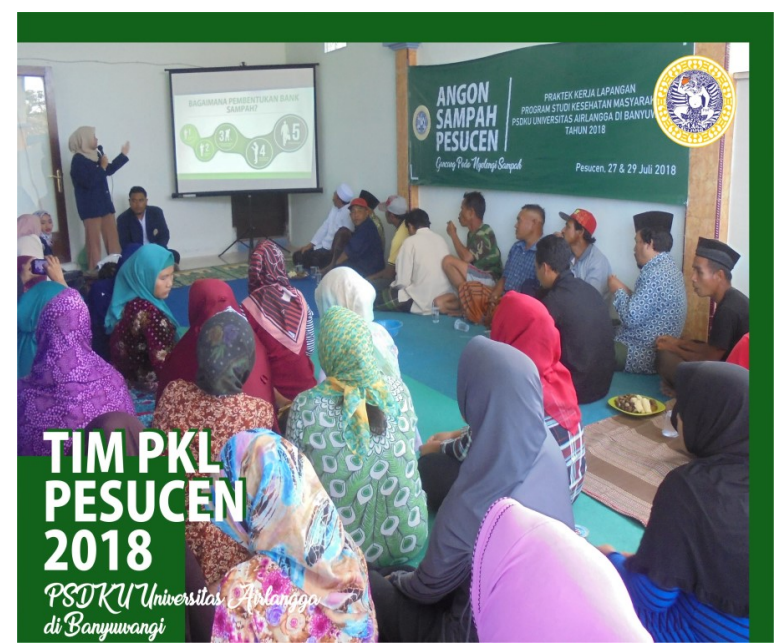

Gambar 2. Sosialisasi pemanfaatan sampah oleh Tim Mahasiswa dalam program Angon Sampah

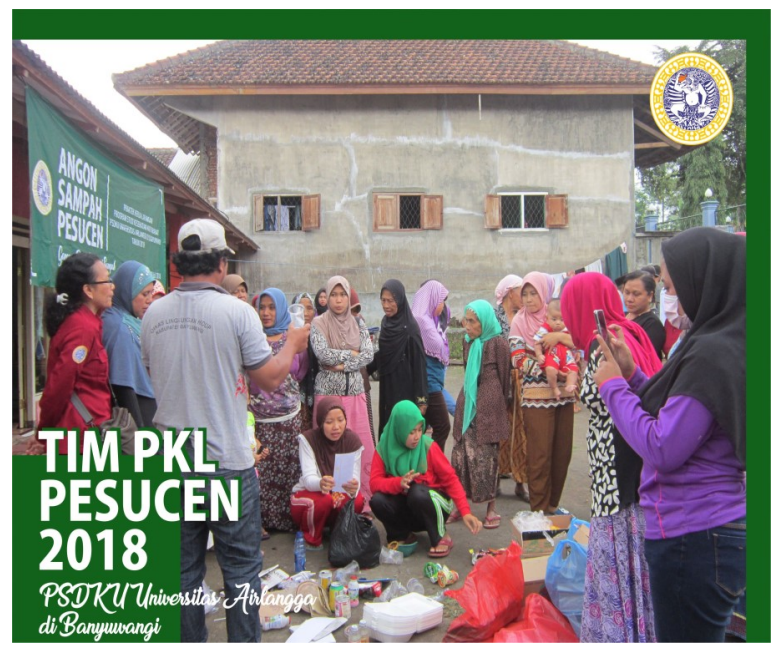

Gambar 4. Pelatihan bank sampah oleh Bank Sampah Banyuwangi dalam program Angon Sampah

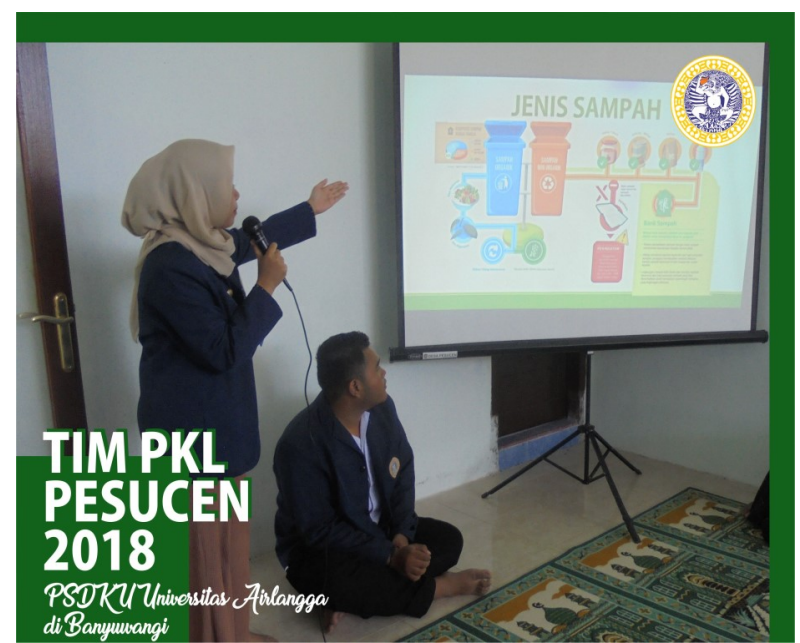

Gambar 3. Sosialisasi pemanfaatan sampah oleh Tim Mahasiswa dalam program Angon Sampah

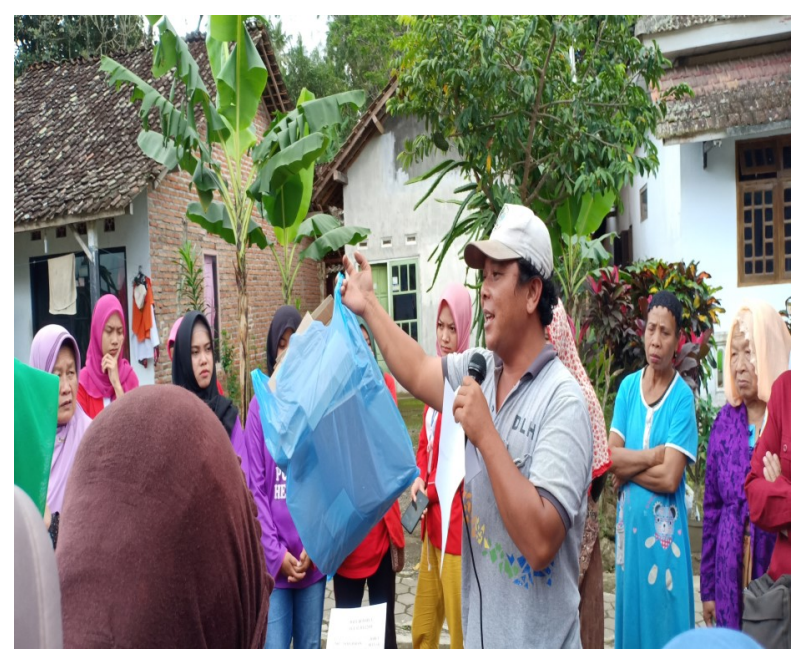

Gambar 5. Pelatihan bank sampah oleh Bank Sampah Banyuwangi dalam program Angon Sampah 


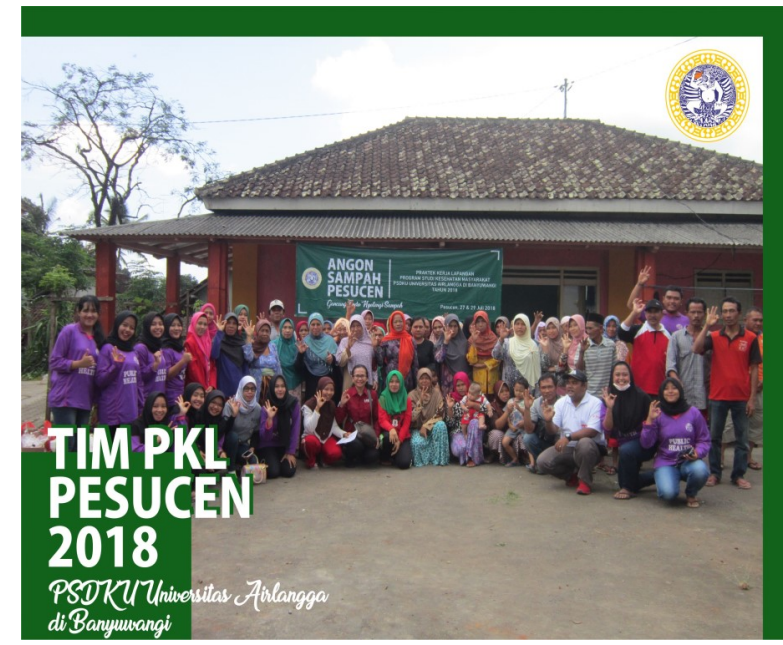

Gambar 6. Foto bersama Tim Mahasiswa, masyarakat sasaran, dan pemateri dalam program Angon Sampah

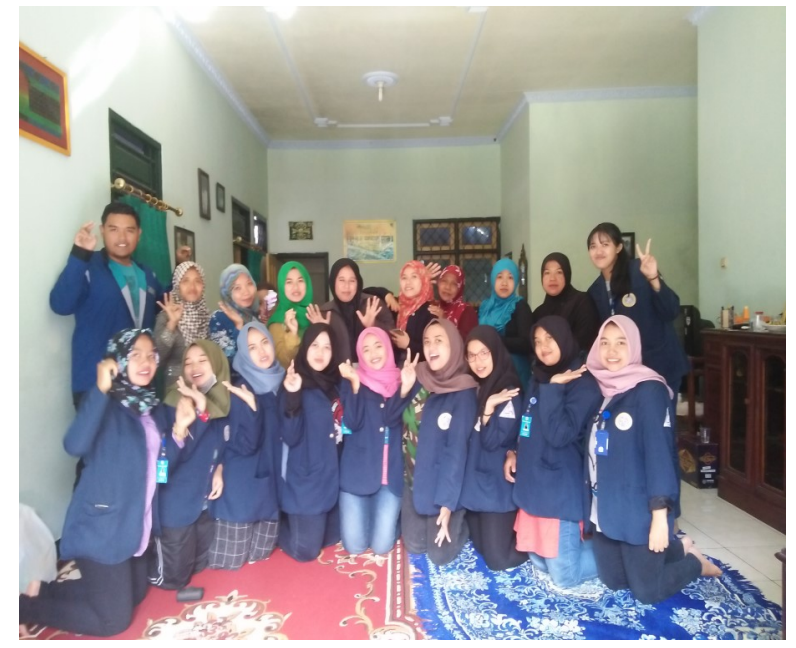

Gambar 8. Foto bersama Tim Mahasiswa dan kelompok Pos Sampah Bangun Ceria

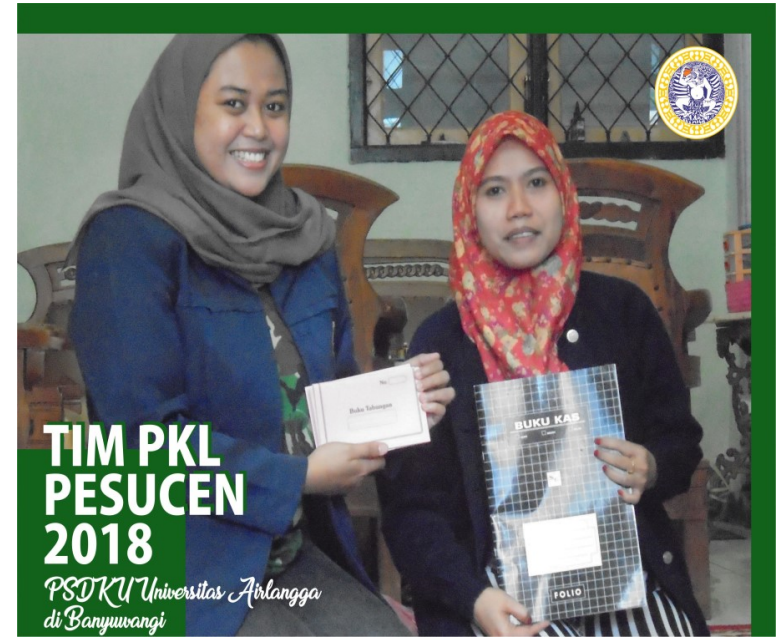

Gambar 7. Serah terima perlengkapan program Angon Sampah antara Tim Mahasiswa dan kelompok Pos Sampah Bangun Ceria

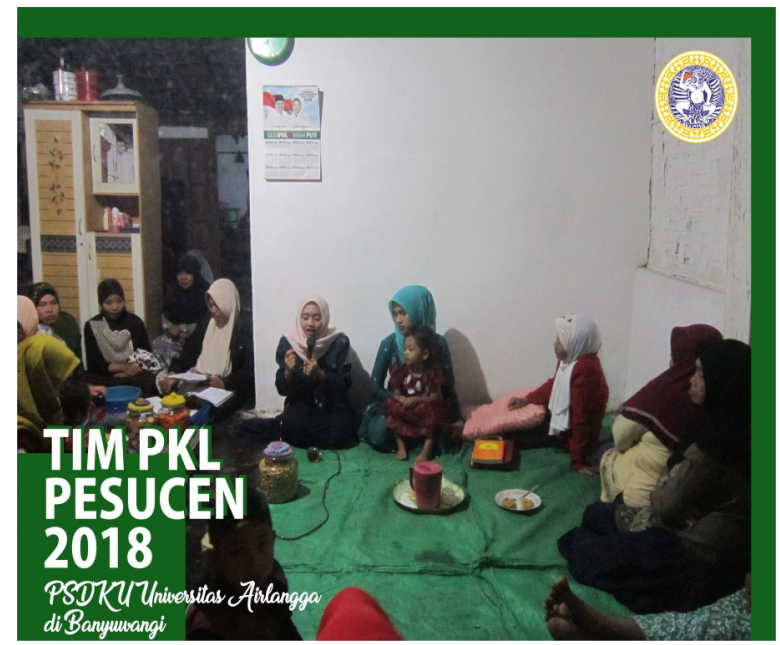

Gambar 9. Sosialisai mengenai program Bank Sampah Pesucen oleh perwakilan Pos Sampah Bangun Ceria kepada masyarakat 